\title{
IMPLEMENTASI SISTEM PENJAMINAN MUTU INTERNAL DALAM MENINGKATKAN MUTU PENDIDIKAN DASAR
}

\author{
Neng Gustini \\ Universitas Islam Negri Sunan Gunung Djati Bandung \\ JI. A.H. Nasution No.105 Cibiru Bandung \\ Email: gustinie1981@gmail.com \\ Yolanda Mauly \\ Universitas Islam Negeri Sunan Gunung Djati Bandung \\ JI. A.H. Nasuition No.105 Cibiru Bandung \\ Email:yolandamaily@gmail.com
}

\begin{abstract}
ABSTRAK
Penjaminan mutu internal diterapkan dengan mengacu pada standar nasonal pendidikan, untuk mewijudkan tujuan pendidikan nasional. Mutu internal kini tidak hanya di terapkan di universitas saja, tetapi di terapkan juga di pendidikan dasar dan menengah. Sehingga penjaminan mutu dan pemenuhan standar mutu pendidikan pada satuan pendidikan dasar dan menengah lebih terjamin dan terarah. Tujuan penelitia ini adalah untuk mengetahui dan mendeksripsikan penerapan siklus Sistem Penjaminan Mutu Internal. Teknik yang digunakan dalam pengumpulan data yaitu: observasi, wawancara, dan studi dokumentasi. Hasil penelitian ini menunjukan bahwa, kegiatan perbaikan mutu yang diterapkan sesuai dengan tahapan siklus SPMI yang dilakukan di SMP Darul Falah Cihampelas meliputi: satu, evaluasi diri sekolah yang berdasarkan pada rapot mutu pendidikan, kedua, perencanaan perbaikan mutu dengan penetapan panitia penjaminan mutu dan menganalisi kermbali hasil evaluasi diri sekolah, ketiga, pelaksanaan perbaikan mutu, keempat, monitoring evaluasi dan hasil peningkatan mutu setelah dilakukannya perbaikan mutu, dan kelima perencanaan mutu kembali untuk tahun mendatang. Hasil dari penerapan penjaminan mutu internal berdampak pada proses pembelajaran yang lebih inovatif, prestasi siswa dan pencapaian sekolah, hingga kepuasan pelanggan baik interal maupun eksternal, serta pemenuhan delapan standar nasional pendidikan.
\end{abstract}

Kata Kunci: Implementasi, Penjaminan Mutu, Mutu Internal

\section{ABSTRACT}

Internal quality assurance is implemented by referring to the national standard of education, to realize national education goals. Internal quality is now not only applied in universities, but also applied in primary and secondary education. So 
that quality assurance and compliance with education quality standards in primary and secondary education units are more guaranteed and directed. The purpose of this research is to find out and describe the implementation of the Internal Quality Assurance System cycle. The techniques used in data collection are: observation, interview, and documentation study. The results of this study indicate that, quality improvement activities implemented in accordance with the stages of the SPMI cycle carried out at Darul Falah Cihampelas Middle School include: one, school self-evaluation based on educational quality report cards, secondly, quality improvement planning by establishing a quality assurance committee and analyzing Kermbali results of school self-evaluation, third, implementation of quality improvement, fourth, monitoring evaluation and results of quality improvement after quality improvement is carried out, and fifth, quality planning returns for the coming year. The results of implementing internal quality assurance have an impact on more innovative learning processes, student achievement and school achievement, to internal and external customer satisfaction, and the fulfillment of eight national education standards.

Key words: Implementation, Quality Assurance, Internal Quality

\section{PENDAHULUAN}

Lembaga pendidikan sebagai sarana dalam menciptakan generasi bangsa yang mampu menjual kualitas dan keunggulan kehidupan bangsa kedepannya diharapkan mampu melahirkan lulusan yang bermutu. Pendidikan kini bukan hanya kegiatan sederhana, melainkan kegiatan yang dinamis, oleh sebab itu perlu dilakukan perubahan dalam pendidikan agar dapat memenuhi tujuan dari pendidikan itu sendiri.

Mutu pendidikan menjadi orientasi dalam penyelenggaraan pendidikan oleh seluruh pemangku pendidikan. Hal ini menjadi penting ketika masih banyaknya masalah yang diakibatkan oleh lulusan yang tidak bermutu. Mutu merupakan suatu proses penetapan dan pemenuhan standar pengelolaan secara konsisten dan berkelanjutan, sehingga konsumen, produsen, dan pihak lain yang berkepentingan memperoleh kepuasan. Lembaga pendidikan seharusnya menetapkan standar mutu yang tidak hanya dinyatakan pada ketentuan pengakuan terakreditasi, tetapi juga harus dilengkapi dengan suatu mekanisme yang jelas bagaimana mutu dilembaga pendidikan itu direalisasikan sesuai dengan mekanisme yang jelas (Uchtiawati \& Zawawi, 2014, hlm. 52-53).

Praturan pemerintah Nomor 19 Tahun 2005 tentang Standar Nasional Pendidikan Pasal 91 berisi pernyataan bahwa setiap satuan pendidikan pada jalur formal dan non formal wajib melakukan penjaminan mutu pendidikan. Penjaminan mutu pendidikan tersebut bertujuan untuk memenuhi atau melampaui Standar Nasional Pendidikan (SNP) (Suharsaputra, 2013, hlm. 383384).

Mutu atau kualitas merupakan segala sesuatu yang mampu memenuhi keinginan maupun kebutuhan pelanggan (meeting the needs of customer) (Gaspersz, 2005, hlm. 4). Mutu dapat diartikan pula sebagai sesuatu yang 
memuaskan dan melampaui keinginan dan kebutuhan pelanggan. Pengertian ini disebut sebagai istilah mutu sesuai presepsi (quality in perceftion).

Menurut ISO 4802 quality management and quality assurance vocabulary (1994) mutu adalah keseluruhan gambaran dan karakteristik suatu produk atau jasa yang berkaitan dengan kemampuan untuk memahami kebutuhan-kebutuhan yang dinyatakan secara langsung/tersurat ataupun tidak langsung/tersirat. Menurut Douglas D Danfort mutu adalah senjata yang paling ampuh untuk memperkuat posisi persaingan di pasar dunia (Umam, 2014, hlm. 281).

Dalam konteks pendidikan, sekolah yang bermutu dapat dilihat melalui spesifikasinya yang berarti standarisasi yang ada. Sekolah yang bermutu yaitu sekolah yang telah memenuhi atau melebihi standar minimal, baik standar kompetensi lulusan, standar pendidikan dan tenaga kependidikan, standar kurikulum, dan sebagainya. Lembaga pendidikan yang bermutu adalah sekolah yang mampu menghasilkan alumni atau lulusan atau peserta didik yang sesuai dengan harapan pelanggan, seperti mengisi peluang dunia kerja, memiliki sikap yang sesuai dengan kebutuhan masyarakat, serta mampu berkontribusi aktif terhadap kemajuan masyarakat, baik masyarakat daerah ataupun bangsa dan negara.

Mutu diidentikkan dengan penilaian pelanggan dan pemenuhan kebutuhan pelanggan. Oleh karena itu, lembaga pendidikan mesti mengidentifikasi kebutuhan pelangganya. Untuk mengetahui kebutuhan pelanggan, lembaga pendidikan hendaknya mengetahui terlebih dahulu siapa pelanggannya. Setelah diketahui pelanggannya, maka lembaga pendidikan harus mengidentifikasi harapan dan kebutuhan pelanggan. Perbedaan harapan dan kebutuhan pelanggan harus diupayakan dapat dipenuhi secara maksimal. Setiap kelompok-kelompok atau setiap pelanggan memiliki kebutuhan dan harapan yang berbeda, lembaga pendidikan hendaknya memiliki cara agar semua harapan dan kebutuhan yang berbeda dapat terpenuhi (Hardianto, 2016, hlm. 170).

Dalam pendidikan mutu produk secara sederhana dapat dilihat dari perolehan nilai atau angka yang dicapai seperti ditunjukan dalam hasil-hasil ulangan dan ujian. Sekolah dianggap bermutu apabila para siswanya sebagian besar atau seluruhnya, memperoleh nilai atau angka yang tinggi, sehingga berpeluang melanjutkan ke jenjang yang lebbih tinggi. Presepsi tersebut tidak keliru apabila nilai atau angka tersebut dianggap sebagai prestasi dan totalitas hasil belajar, yang dapat dipercaya menggambarkan derajat perubahan tingkah laku atau penguasaan kemampuan yang menyangkut aspek kognitif, efektif, dan psikomotorik.

Lembaga satuan pendidikan harus memiliki standar mutu sebagai landasan dalam melaksanakan penjaminan mutu pendidikan. Secara nasional standar mutu pendidikan merujuk kepada Peraturan pemerintah Nomor 19 Tahun 2005 yang menyatakan bahwa Standar Nasional Pendidikan (SNP) memiliki delapan standar, yang masing-masing standar tersebut membentuk serangkaian input, proses (isi kurikulum, proses pembelajaran, penilaian) dan output (standar komptensi lulusan).

Konsep implementasi manajemen mutu terpadu dalam dunia pendidikan adalah institusi pendidikan yang memposisikan dirinya sebagai institusi jasa. 
Jasa yang diberikan kepada pelanggan merupakan sesuatu yang bermutu dan memberikan kepuasan pada pelanggan/Stakeholders. Untuk itu institusi pendidikan membutuhkan suatu sistem manajemen yang mampu memberdayakan institusi agar lebih bermutu.

Sistem penjaminan mutu adalah suatu mekanisme yang sistematis, terintegrasi, dan berkelanjutan untuk memastikan bahwa seluruh proses penyelenggaraan telah sesuai dengan standar mutu. Dalam sistem penjaminan mutu pendidikan dibedakan menjadi dua bagian, yaitu Sistem Penjaminan Mutu Eksternal (SPME), dan Sistem Penjaminan Mutu Internal (SPMI). Dalam Permendikbud Nomor 28 Tahun 2016 tentang Sistem Penjaminan Mutu Pendidikan Dasar dan Menengah dijelaskan bahwa Sistem Penjaminan Mutu Internal (SPMI) adalah suatu kesatuan unsur yang terdiri atas kebijakan dan prosesnyang terkait untuk melakukan sistem penjaminan mutu pendidikan yang dilaksanakan oleh setiap satuan pendidikan dasar dan menengah untuk menjamin terwujudnya pendidikan yang bermutu yang memenuhi atau melampaui Standar Nasional Pendidikan (SNP) (Menteri Pendidikan dan Kebudayaan Republik Indonesia, 2016).

Sistem Penjaminan Mutu Pendidikan (SPMP) adalah sub sistem dari Sisdiknas dengan fungsi utama meningkatkan mutu pendidikan. Penjaminan mutu pendidikan adalah kegiatan sistemik dan terpadu oleh satuan pendidikan, pemerintah, pemerintah daerah, dan masyarakat untuk menaikkan tingkat kecerdasan kehidupan bangsa melalui pendidikan (Hendrowati, 2016).

Sistem penjaminan mutu yang berjalan di dalam sekolah dan dijadikan oleh seluruh komponen dalam sekolah disebut sebagai Sistem Penjaminan Mutu Internal (SPMI). Sistem Penjaminan Mutu Internal (SPMI) mencakup seluruh aspek penyelenggaraan pendidikan dengan memanfaatkan berbagai sumberdaya untuk mencapai Standar Nasional Pendidikan (SNP) (Jamaluddin \& Sopiah, 2018, hlm. 100). Lembaga satuan pendidikan berperan dalam melaksanakan sistem yang terdiri atas organisai, kebijakan, dan proses, yang terkait dalam melaksanakan penjaminan mutu pendidikan untuk menjamin terwujudnya pendidikan yang bermutu, dalam rangka memenuhi atau bahkan melampaui SNP.

Sistem Penjaminan Mutu Internal (SPMI) di sekolah harus dilakukan oleh seluruh anggota sekolah yaitu kepala sekolah, guru, dan staf sekolah sesuai dengan tugasnya masing-masing, siswa dan lainnya. Ada lima tahapan dalam siklus yang harus dilaksanakan dalam implementasi SPMI yaitu pemetaan mutu sekolah, perencanaan peningkatan mutu sekolah, pelaksanaan program penjaminan mutu, monitoring dan evaluasi, serta penetapan standar dan penyusunan strategi mutu baru (Sani, Arifin, Rif'an, \& Triatna, 2018).

Tahap pertama yaitu pemetaan mutu sekolah. Tahap ini ialah peroses pemetaan mutu sekolah melalui kegiatan evaluasi diri sekolah (EDS). Dalam tahap evaluasi diri sekolah kepala sekolah dengan dukungan pengawas sekolah melaksanakan EDS berasama Tim Penjaminan Mutu Sekolah (TPMS) yang terdiri dari perwakilan guru (Sani dkk., 2018). Kegiatan ini penting untuk melibatkan seluruh angota sekolah untuk mendapatkan informasi dan evaluasi dari berbagai sisi. Visi, misi dan tujuan sekolah dapat direvisi dan dikembangkan sesuai hasil pemetaan ini. Hal ini penting karena visi, misi, dan 
tujuan merupakan pusat pengelolaan sekolah dan alat ukur untuk memenuhi harapan sekolah.

Tahap yang kedua adalah perencanaan peningkatan mutu sekolah. Tahap ini membuat perencanaan peningkatan mutu sekolah, yang mencakup kedalam manajemen sekolah termasuk kurikulum, kegiatan ekstrakulikuler, sumber daya manusia, sarana prasarana, dan lain sebagainya. Perencanaan peningkatan mutu dilaksanakan dengan menggunakan peta mutu sebagai masukan utama disamping dokumen kebijakan pemerintah seperti kurikulum dan standar nasional pendidikan, serta dokumen rencana strategi pengembangan sekolah.

Tahap ketiga yaitu pelaksanaan program pejaminan mutu sekolah. Dimana dalam proses pelaksanaan program penjaminan mutu ini diterapkan dalam proses pembelajarannya, seperti mengembangkan materi dan pendekatan proses pembelajaran, kegiatan ekstrakulikuler, dan kegiatan lainnya yang berkaitan dengan program penjaminan mutu sekolah. Dalam proses pembelajaran, guru dan siswa akan belajar bagaimana menerapkan pembelajaran interktif dan integratif melalui pendekatan ilmiah untuk membangun pengetahuan, keterampilan dan prilaku.

Tahap ke empat adalah monitoring dan evaluasi. Hal-hal yang dimonitoring dan evaluasi secara umum dilihat dari aspek manajemen, proses belajar dan hasilnya, dan kegiatan ekstrakulikuler dan hasilnya, dampak menjaminan mutu sekolah terutama pengetahuan, keterampilan dan perilaku perubahan anggota sekolah, dukungan stakeholder dan keterlibatan masyarakat.

Tahap kelima adalah penetapan standar dan penyusunan strategi mutu baru. Tahap ini merupakan penyusunan strategi baru perlu dilakukan jika sekolah atau lembaga pendidikan belum mampu mencapai Standar Nasional Pendidikan (SNP) berdasarkan strategi sebelumnya. Sekolah yang telah mampu memenuhi SNP dapat menetapkan standar mutu baru di atas Standar Nasional Pendidikan (Direktorat Jenderal Pendidikan Dasar dan Menengah, 2016).

Sistem Pejaminan Mutu Internal (SPMI) menjadikan sekolah sebagai pelaku utama atau ujung tombak penjaminan mutu pendidikan. SPMI menciptakan sekolah sebagai organisasi pembelajar dan menciptakan pentingnya budaya mutu. Mutu tidak lagi diposisikan sebagai beban melainkan kebutuhan, bahkan dijadikan sebagai gaya hidup. Mutu pendidikan kini tidak lagi menjadi tanggung jawab pihak tertentu, melainkan menjadi urusan setiap orang. Setiap warga sekolah diharapkan berpartisipasi secara aktif dan memberikan kontribusi terhadap peningkatan mutu pendidikan di sekolah (Puspitasari, 2018, hlm. 340-341).

Dalam peroses implementasi tahap sistem penjaminan mutu internal ini sekolah diberi bimbingan dan diberi pelatihan oleh Lembaga Penjaminan Mutu Pendidikan (LPMP) yang bisa dijadikan acuan dalam proses pengimplementasian Sistem Penjaminan Mutu Internal. Jika penjaminan mutu dilakukan secara benar, maka akan terjadi peningkatan mutu proses pendidikan di lembaga satuan pendidikan. Indikator ketercapaian peningkatan mutu yang paling nyata ialah peningkatan proses pembelajaran dan hasil belajar atau prestasi peserta didik. Proses pembelajaran yang memenuhi standar dicirikan 
dengan keterlibatan (aktivitas) peserta didik dalam belajar dan terciptanya pembelajaran yang menyenangkan.

Jika belum diperoleh peningkatan mutu sesuai yang diharapkan, kepala sekolah dan tim penjaminan mutu sekolah perlu melakukan refleksi dan mengidentifikasi penyebab keadaan tersebut. Analisis kualitatif perlu dilakukan secara lebih mendalam untuk memperbaiki program dan kegiatan pada semester selanjutnya (Sani dkk., 2018, hlm. 38)

Hasil pemetaan mutu pendidikan secara nasional tahun 2014 menunjukan hanya sekitar $16 \%$ satuan pendidikan yang memenuhi standar Nasional pendidikan (SNP), sekitar 40\% Standar pelayanan Minimal (SPM) dan 34\% masih di bawah SPM. Hal ini disebabkan karena masih banyak pengelola pendidikan yang tidak mengerti makna standar mutu pendidikan. Selain itu pada umumnya pengelola satuan pendidikan belum memiliki kemampuan untuk menjamin bahwa proses pendidikan yang dilaksanakan memenuhi standar kualitas yang ditetapkan (Asia, 2017, hlm. 47).

Berdasarkan kondisi tersebut maka pemerintah melakukan upaya untuk mempercepat pencapaian Standar Nasional Pendidikan dengan mengeluarkan Permendikbud No 28 Tahun 2016 tentang Sistem Penjaminan Mutu Pendidikan Dasar dan Menengah. Agar pelaksanaan SPMI dapat dilakukan oleh satuan pendidikan secara optimal, maka ditunjuk sekolah model untuk melaksanakan penjaminan mutu secara mandiri. Sekolah model ialah sekolah yang ditetapkan dan dibina oleh LPMP untuk menjadi sekolah acuan bagi sekolah di sekitarnya dalam melaksanakan penjaminan mutu. Salah satu sekolah model yang ditetapkan oleh LPMP Kabupaten Bandung Barat adalah SMP Darul Falah Cihampelas.

Dalam pelaksanaan Implementasi Sistem Penjaminan Mutu Internal di SMP Darul Falah, diketauhui bahwasannya SMP Darul Falah di percaya oleh LPMP sebagai Sekolah Model SPMI di Kabupaten Bandung Barat. Dalam proses implementasi SPMI dilakukan beberapa siklus, yang dimulai dengan menganalisis pemetaan mutu yang mengacu pada evaluasi diri sekolah. Setelah melakukan analisis dari delapan Standar Nasional Pendidikan ditemukan empat standar yang perlu diperbaiki, yaitu standar isi, standar kompetensi lulusan, standar proses dan standar penilaian.

Budaya mutu menjadi kewajiban bagi setiap satuan pendidikan dan elemennya untuk diimplementasikan, program yang dirasakan langsung oleh SMP Darul Falah saat ini diantaranya ialah Sistem Penjaminan Mutu Internal (SPMI). Walaupun program ini sudah berjalan kurang lebih satu tahun tetapi dampak pisitifnya sudah dirasakan langsung walaupun belum begitu signifikan. Dengan demikian untuk terselenggaranya budaya mutu yang baik dan konsistennya berbagai program yang berbasis nilai-nilai yang dikembangkan, maka pihak sekolah secara rutin melakukan mentoring evaluasi terhadap kegiatan-kegiatan yang sudah dijalankan di sekolah dan secara terus menerus melakukan pembinaan terhadap seluruh warga sekolah. Oleh karena itu peneliti ingin mengetahui sejauh mana implementasi Sistem Penjaminan Mutu Internal di SMP Darul Falah Cihampelas dalam meningkatkan mutu Pendidikan dasar. 


\section{METODE PENELITIAN}

Secara garis besar langkah-langkah penelitian atau pola umum metodelogi penelitian terdiri dari beberapa tahapan, yaitu: 1) pendekatan dan metode penelitian, 2) jenis dan sumber data penelitian, 3) teknik pengumpulan data penelitian, 4) teknik analisis data penelitian, 5) tempat dan waktu penelitian, dan 6) teknik pemeriksaan uji absah data.

Penelitian ini menggunakan penelitian kualitatif. Penelitian kualitatif adalah metode penelitian yang berlandaskan pada filsafat postpositivisme, digunakan untuk meneliti pada kondisi objek yang alamiah, (sebagai lawannya adalah eksperimen). Dimana penelitian adalah sebagai instrument kunci, pengambilan sempel sumber data dilakukan dengan secara purposive dan snowball, teknik pengumpulan data dengan triangulasi (gabungan), analisis data bersifat induktif atau kualitatif dan hasil penelitian kualitatif lebih menekankan pada makna dari pada generalisasi (Sugiyono, 2014, hlm. 15).

Metode penelitian kualitatif sering disebut juga dengan metode penelitian naturalistik karna penelitiannya dilakukan dengan kondisi yang sangat alamiah (natural seting). Sedangkan filsafat postpositivisme sering juga disebut sebagai paradigma interpretif dan konstruktif, yang memandang realitas sosial sebagai sesuatu yang holistik atau utuh, kompleks, dinamis, penuh makna, dan hubungan gejala bersifat interaktif (reciprocual) (Sugiyono, 2014).

Penulis menggunakan tipe penelitian deskriptif untuk menggambarkan secara jelas mengenai masalah-masalah yang diteliti yaitu mengenai Implementasi Sistem Penjaminan Mutu Internal di SMP Darul Falah Cihampelas Kabupaten Bandung Barat, dalam pelaksanaanya peneliti mengumpulkan, mengklarifikasik data sebagaimana adanya.

\section{HASIL DAN PEMBAHASAN \\ Pemetaan Sistem Penjaminan Mutu Internal di SMP Darul Falah Cihampelas}

Penjaminan mutu internal dilakukan beberapa tahapan, yang pertama yaitu pemetaan mutu sekolah. Proses pemetaan mutu pendidikan dilakukan secara nasional dengan bantuan aplikasi yang disediakan oleh Kementrian Pendidikan dan Kebudayaan. Aplikasi yang disediakan oleh Kemendikbud sering disebut dengan Rapot Penjaminan Mutu Pendidikan (Rapot PMP), yang merupakan penilaian dan capaian sekolah selama satu tahun pembelajaran. Data yang terdapat dalam ropot PMP dapat digunakan oleh lembaga pendidikan sebagai data Evaluasi Diri Sekolah (EDS) untuk keperluan pemetaan mutu pendidikan.

Dalam rapot mutu terdapat nilai-nilai ketercapaian sekolah, sama halnya dengan rapot pada umumnya, yakni untuk mengetahui perkembangan sekolah selama satu tahun kebelakang. Satuan pendidikan dapat memperdalam EDS dengan melakukan analisis pemetaan mutu dan memperkaya data EDS secara kualitatif. Dalam memperkaya data EDS secara kualitif dilakukan dengan melibatkan seluruh stakeholder yang mengetahui kondisi sekolah baik itu kepala sekolah, wakil kepala sekolah, pendidik dan tenaga kependidikan hingga peserta didik.

Kepala sekolah Drs. H. Baehaqi M.Si sebagai penanggung jawab pelaksanaan SPMI dengan dukungan pengawas sekolah melaksanakan EDS 
bersama tim pengembangan mutu sekolah (TPMS) yang terdirir dari perwakilan guru. TPMS dengan mempergunakan instrument yang disusun dan dibuat bersama untuk menetapkan profil kinerja sekolah berdasarkan indikator pencapaian. Data dan informasi yang didapatkan kemudian dianalisis untuk mengidentifikasi kelebihan dan kelemahan, atau permasalahan sekolah yang perlu diatasi. Hal yang perlu diperhatikan dalam memperoleh data EDS yaitu kejujuran pengisi dan akurasi data. Karna sekecil apapun data yang ada merupakan informasi yang sangat penting, sebagai dasar untuk proses peningkatan mutu satuan pendidikan.

Instrument yang disusun didasarkan pada Standar Nasional Pendidikan (SNP) dan akan memberikan tujuan untuk menyediakan informasi bagi rencana pengembangan mutu sekolah. Permsalahan dan data inti yang terdapat dalam instrument tersebut merefleksikan aspek-aspek yang penting bagi sekolah, yang diperlukan untuk merencanakan perbaikan sekolah. Sekolah perlu melaporkan situasi nyata yang ada disekolah, dengan demikian proses EDS akan berjalan dengan baik dan proses perencanaan perbaikan sekolah pun akan terselenggara dengan baik.

Evaluasi diri merupakan aspek penting dalam proses penjaminan mutu, dan dalam proses akreditasi satuan pendidikan. Dalam proses analisis kelebihan dan kelemahan dilakukan dengan analisis SWOT. Sekolah mengembangkan instrument evaluasi diri sesuai dengan kondisi sekoah yang mengacu kepada standar mutu yang telah ditetapkan oleh pemerintah, yaitu 8 standar nasional pendidikan yang meliputi: 1) standar kompetensi lulusan, 2) standar isi, 3) standar proses, 4) standar penilaian, 5) standar pendidik dan tenaga kependidikan, 6) standar sarana dan prasarana, 7) standar pembiayaan, dan 8) standar pengelolaan. Setelah meakukan analisis dalam proses evaluasi diri, dari delapan standar tersebut, sekolah dengan bimbingan LPMP menyimpulkan untuk memfokuskan melakukan perbaikan pada empat standar nasional pendidikan yang masuk kedalam standar akademik yaitu standar kompetensi lulusan, standar isi, standar proses dan standar penilaian.

Terkait standar kompetensi lulusan, hasil pemetaan mutu pendidikan yang dilakukan melalui Evaluasi Diri Sekolah (EDS) yang mengacu kepada rapot mutu ditemukan permaslaahan dalam standar kompetensi lulusan. Akar permasalahan yang terdapat dalam standar kompetensi lulusan yaitu peserta didik SMP Darul Falah masih rendah tingkat kesadaran akan pentingnya hidup bersih dan hidup sehat. Dalam hal standar Isi, proses pemetaan mutu pendidikan yang dilakukan dengan mengacu kedalam rapot mutu ditemukan akar permasalahan pada standar isi pendidikan. Permasalahan yang terjadi dan perlu diperbaiki yaitu kurikulum satuan pendidikan dokumen 3 belum tersusun dengan lengkap. Sedangkan dalam hal standar proses, menjadi standar yang perlu dilakukan perbaikan. Akar permasalahan yang ditemukan dalam proses EDS yaitu masih banyaknya guru SMP Darul Falah yang belum menyusun RPP. Yang terakhir yaitu stadar penilaian ialah permasalah mengenai standar penilaian. Dalam standar penilaian akar permasalahan yang ditemukan yaitu masih banyaknya guru SMP Darul Falah yang belum melaksanakan penilaian hasil pembelajaran sesuai prosedur yang berlaku. 


\section{Perencanaan Sarana dan Prasarana di SMP Darul Falah Cihampelas}

Perencanaan yang matang dalam setiap kegiatan tentunya sangat diperlukan. Kegiatan tidak akan terlaksana dengan baik jika tanpa perencanaan. Perencanaan merupakan langkah awal dalam pelaksanaan suatu kegiatan untuk pencapaian tujuan. Dalam ilmu manajemen perencanaan merupakan fungsi pertama dalam memulai suatu kegiatan. Tanpa adanya perencanaan mutu pendidikan tidak akan terlaksana secara optimal.

Setiap lembaga pendidikan tentunya memiliki rencana yang sudah ditetapkan pada masing-masing instansi untuk meningkatkan mutu pendidikan yang ada di lembaganya tersebut. Peningkatan mutu pendidikan sangat penting karna dengan meningkatnnya mutu pendidikan di sebuah sekolah maka akan mempengaruhi mutu pendidikan di Indonesia pula.

Perencanaan sangat berperan penting dalam peningkatan mutu pendidikan, jika dalam setiap kegiatan tidak didahului dengan sebuah perencanaan yang matang maka bisa terjadi kesalahan dalam proses pelaksanaan, yang akan berdampak pada kebehasilan proses peningkatan mutu pendidikan.

Dalam proses perencanaan pemenuhan mutu, kepala sekolah selaku penanggung jawab pelaksanaan SPMI beserta dewan guru melakukan penentuan struktur kerja kepanitiaan dalam proses peningkatan mutu di SMP Darul Falah. Pembentukan struktur kerja mengacu pada TPS (tim pengembangan mutu sekolah) yang sudah terbentuk sebelumnya dan melakukan beberapa perubahan sesuai dengan kesepakatan seluruh dewan guru SMP Darul Falah.

\section{Struktur Kerja Tim Penjaminan Mutu Sekolah}

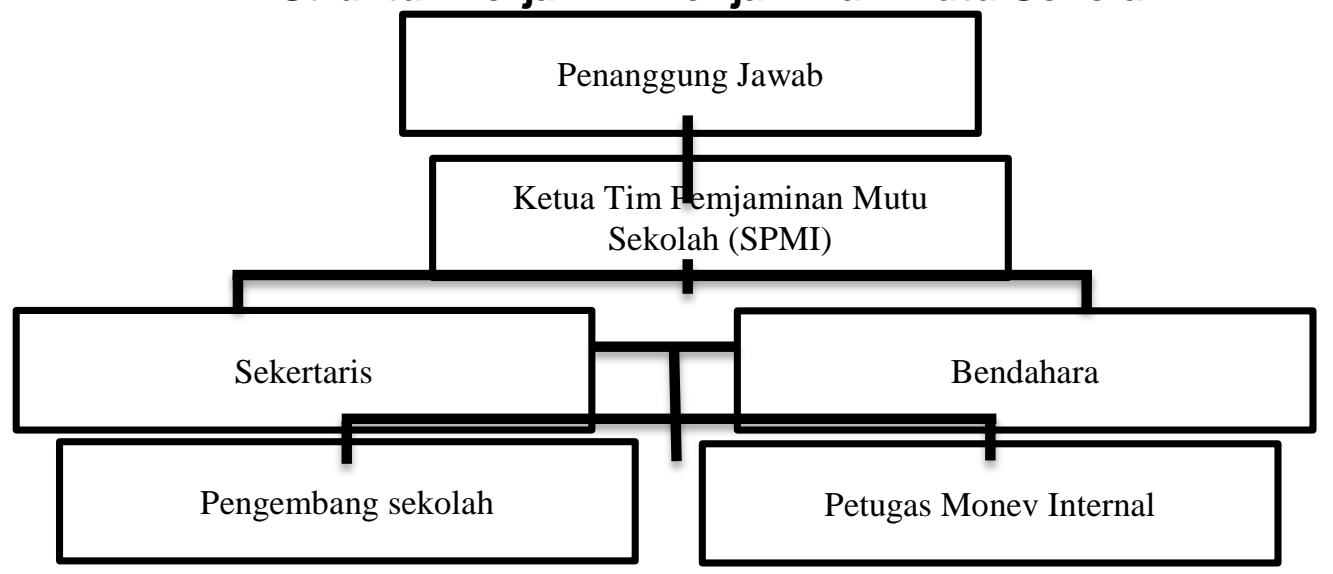

Gambar 1. Struktur Penjaminan Mutu Sekolah

Setelah menetapkan struktur kerja dan kepanitiaan SPMI selanjutnya menganalisis memilih dan memilah apa yang perlu dilakukan dalam pemenuhan standar mutu dengan mengacu pada hasil Evaluasi Diri Sekolah (EDS). Hasil evaluasi diri sekolah ditemukan ada empat standar yang perlu dilakukan perencanaan lebih lanjut agar mencapai standar nasional pendidikan, yaitu Standar Isi, Standar Kompetensi Lulusan, Standar Proses, dan Standar Pembiayaan. Keempat standar tersebut saling berkaitan satu dengan yang 
lainnya karna merupakan standar nasional pendidikan yang masuk kedalam standar akademik, dimana jika salah satu standar tidak terpenuhi maka akan mempengaruh standar yang lain.

Dalam proses perencanaan pemenuhan standar mutu pendidikan yang perlu diperhatikan ialah pemenuhan indikator standar nasional pendidikan, dan yang harus dipersiapkan dalam proses peningkatan mutu, antara lain adalah standar kompetensi lulusan, standar isi, standar proses, dan standar penilaian.

Dalam hal standar kompetensi lulusan, kompetensi lulusan menjadi salah satu bagian terpenting dalam peroses peningkatan mutu. Lulusan yang baik menjadi salah satu tolak ukur keberhasilan sekolah dalam mendidik peseta didik dan menciptakan generasi yang mampu bersaing. Tujuan dari pendidikan itu salah satunya ialah melahirkan lulusan yang bermutu dan mampu berdaya saing. Berdasarkan hasil wawancara dengan ketua tim pengembangan mutu sekolah SMP Darul Falah, program perencanaan yang dilakukan dalam proses pemenuhan standar kompetensi lulusan ialah dengan melakukan sosialisasi dan pembinaan secara terus menerus dan berkala yang melibatkan tim penjaminan mutu, seluruh guru dan staf.

Standar Isi yaitu setiap instansi pendidikan tentunya memiliki rencana yang sudah ditetapkan dalam setiap kegiatan. Sama halnya dengan perencanaan dalam pemenuhan mutu standar isi pendidikan. Pemenuhan standar isi dalam pendidikan sangat penting dilakukan dalam proses ketercapaian mutu dalam bidang akademik atau pembelajaran peserta didik. Jika dalam setiap kegiatan tidak dilakukan perencanaan maka akan bisa terjadi kesalahan program yang akan berdampak terhadap keberhasilan proses peningkatan mutu standar isi.

Berdasarkan hasil wawancara dengan ketua tim pengembangan mutu sekolah SMP Darul Falah, program perencanaan yang dilakukan dalam proses pemenuhan standar isi ialah dengan mengadakan wokshop penyusunan kurikulum sekolah dokumen 3 (tiga), dimana kegiatan wokshop ini diselenggarakan agar tercapainya pemahaman seluruh SMP Darul Falah mengenai pembuatan RPP yang terbaru dan sesuai dengan perkembangan jaman.

Standar proses dalam pendidikan merupakan seluruh rangkaian kegiatan pelaksanaan yang dilakukan di sekolah yang berhubungan dengan pelaksanaan proses pembelajaran. Keberhasilan standar proses akan mempengaruhi standar kompetensi lulusan, karna kedua standar tersebut merupakan garis lurus yang berhubungan dengan peserta didik. Berdasarkan hasil wawancara dengan ketua tim pengembangan mutu sekolah SMP Darul Falah, program perencanaan yang dilakukan dalam proses ialah dengan melakukan wokshop dan In House Training (IHT). In House Training merupakan pemberian wawasan dan peningkatan keterampilan kepada guru dan staf dalam melaksanakan proses kegiatan pembelajaran.

Standar penilaian merupakan salah satu cara dari evaluasi kegiatan, sejauh mana kegiatan terlaksana dan pencapaian apa yang didapatkan dari kegiatan tersebut. Penilaian dalam proses pembelajaran sangat penting karna dari penilaian sekolah, guru dan peserta didik dapat melihat sejauh mana ketercapaian lembaga dalam penerapan seluruh komponen atau tujuan pendidikan terlaksana, dan sejauh mana pemahaman peserta didik dalam 
peroses pembelajar selama satu semester kebelakang. Berdasarkan hasil wawancara dengan ketua tim pengembangan mutu sekolah SMP Darul Falah dan dengan melihat rapot mutu capaian nilai pada standar penilaian ialah 5,06 merupakan nilai yang cukup baik dari seluruh ketercapaian nilai standar nasional pendidikan. Tetapi karna standar penilaian merupakan serangkaian standar nasional yang termasuk kedalam standar akademik maka standar penilaian dimasukan kedalam standar yang perlu dilakukan perbaikan. Program yang dilakukan dalam prencanaan standar penilaian ialah dengan melakukan Wokhsop atau In Hous Training (IHT).

\section{Pelaksanaan Pemenuhan Mutu Pendidikan SMP Darul Falah Cihampeals}

Setelah proses perencanaan dilakukan, hal selanjutnya yang merupakan bagian terpenting adalah pelaksanaan. Dalam siklus SPMI pelaksanaan merupakan langkah ketiga dalam mengimplementasikan SMPI di sekolah. Pelaksanaan merupakan penggerak dari hasil perencanaan kegiatan atau program yang telah ditetapkan sesuai dengan prosedur dan kebutuhan sekolah.

Untuk pengembangan mutu SMP Darul Falah tentunya sekolah melakukan pemfokusan pengembangan mutu salah satunya difokuskan pada kompetensi lulusan. Lulusan menjadi salah satu tolak ukur dari keberhasilan sekolah dalam pencapaian visi, misi dan tujuan sekolah, selain itu ditunjang dengan mutu pendidik dan tenaga pendidik dan standar penunjang akademik dan manajerial lainnya.

Dalam proses pelaksanaan pemenuhan mutu, seluruh pemangku kegiatan pendidikan mualai dari kepala sekolah, guru, staf, peserta didik hingga masyarakat sekitar dituntut dapat memberikan perhatian yang besar untuk slalu meningkatkan kualitas sekolah, terutama dalam pelaksanaan kegiatan pembelajaran. Agar selalu aktif, kreatif, bersedia meningkatkan diri, baik melalui program pelatihan maupun pengembangan yang dilakukan oleh pihak sekolah maupun oleh Lembaga Penjaminan Mutu Pendidikan (LPMP).

Meningkatkan mutu pendidikan tidak terlepas dari pencapaian seluruh standar nasional pendidikan. Dalam hal ini sekolah dituntut untuk meningkatkan kualitas standar akademik dan standar manajerial, agar sekolah mampu memenuhi seluruh target atau tujuan standar nasional pendidikan dan berhasil melahirkan lulusan yang bermutu dan berdaya saing.

Pelaksanaan pelatihan, pembinaan, sosialisasi yang telah direncanakan dalam pemenuhan standar dilaksanakan selama satu tahun pembelajaran, atau dua smester. Pelaksanaan pelatihan ini bertujuan untuk meningkatkan kualitas standar akademik (Standar Kompetensi Lulusan, Standar Isi, Standar Proses, dan Standar Penilaian) hingga tercapainya penilaian mutu yang menjadi tolak ukur keberhasilan mutu pendidikan. Pembahasan dalam pelatihan, pembinaan dan sosialisasi ini diantaranya berkaitan dengan pemberian pemahaman terhadap guru dalam penyusunan atau penyepurnaan pembuatan RPP, pembiasaan kepada peserta didik dalam penerapan akhlak hidup bersih dan keaktifan belajar, dan pelatihan pemenuhan proses pembelajaran dan pentingnya penilaian setiap kegiatan kepada guru dan staf SMP Darul Falah.

Pada pelaksanaan pengembangan mutu pendidikan selain dalam penyusunan RPP guru dilatih penerapan metode pembelajaran yang menyenangkan, untuk memberikan materi atau melakukan kegiatan 
pembelajaran tidak hanya berfokus dikelas tetapi bisa dengan melakukan kegiatan pembelajaan di luar kelas, dengan harapan peserta didik lebih rileks dan mampu membuka fokus terhadap materi ajar yang diberikan. Dengan demikian pemahaman terhadap materi yang disampaikan lebih mudah dicerna dan diingat oleh peserta didik.

\section{Monitoring dan Evaluasi Pemenuhan Mutu Pendidikan SMP Darul Falah Cihampelas}

Monitoring dan evaluasi merupakan langkah keempat yang dilakukan dalam mengimplementasikan SPMI di sekolah. Kegiatan monitoring dan evaluasi merupakan kegiatan yang berbeda tetapi saling berkesinambungan. Dalam perencanaan tim pelaksanaan monev dengan tim pengembangan mutu di pisahkan, tetapi masih dalam ruang lingkup guru SMP Darul Falah. Dengan adanya proses monitoring dan evaluasi maka akan diketahui dimana letak kekurangan dan kelebihan dalam setiap proses pelaksanaan pemenuhan mutu SMP Darul Falah.

Adapun pelaksanaan monitoring dan evaluasi yang dilakukan dalam proses penerapan SPMI adalah sebagai berikut. Pertama yaitu standar kompetensi lulusan. Kegiatan yang dilaksanakan dalam pemenuhan pemutu standar kompetensi lulusan ialah pembinaan secara terus menerus dan berkala yang melibatkan Tim Penjaminan Mutu Pendidikan Sekolah (TPMPS), seluruh guru dan staf. Dari hasil monitoring dan evaluasi kegiatan pembinaan tersebut panitia monev menyimpulkan bahwa TPMPS sudah menjalankan tugas dengan baik, pembinaan terhadap peserta didik pun terus menerus dilakukan oleh kepala sekolah dan guru lainnya, mengenai pentingnya hidup bersih dan kesadaran akan lingkungan bersih karna merupakan sebagian dari penguatan akhlak, dan pengadaan alat-alat kebersihan pun sudah memadai. Pola pembinaan tehadap peserta didik dilakukan terus menerus dengan pemberian contoh dari guru-guru SMP Darul Falah, dan dengan mengadakan kegiatan lomba kebersihan kelas dan melaksanakan kegiatan Jumsih harus ditegaskan. Dengan demikian ketercapaian penerapan kompetensi lulusan dapat dilihat dengan adanya kesadaran peserta didik akan kebersihan lingkungan dan diri sudah menigkat.

Pelaksanaan monitoring dan evaluasi yang kedua adalah terkait standar isi. Kegiatan yang dilaksanakan dalam standar isi ialah Workhshop penyusunan dan penyempurnaan dokumen 3 yaitu RPP. Dari hasil monitoring kegiatan pelatihan tersebut panitian monev menyimpulkan pelaksanaan dari kegiatan yang sudah dilakukan berjalan dengan baik sesuai dengan yang telah direncanakan, dari segi narasumber pun sesuai dengan yang sekolah harapkan dari segi durasi waktu saat pemberian materi hingga pemberian materi yang mudah dipahami oleh guru-guru. Untuk guru-guru yang mengikuti pelatihan pun sangat serius mengikuti kegiatan pelatihan, dan hasil dari pelatihan tersebut pemahaman guru terhadap penyusunan RPP lebih meningkat dan gurupun sudah dapan membuat RPP dengan baik. Ketercapaian dalam pemenuhan mutu standar isi dilihat dengan cara pemeriksanaan dan perbaikan RPP.

Pelaksanaan monitoring dan evaluasi yang ketiga adalah standar proses. Kegiatan yang dilaksanakan dalam pemenuhan mutu standar proses ialah Workshop atau In House Training (IHT). Dari hasil monitoring dan evaluasi 
kegiatan pelatihan tersebut, panitia monev menyimpulkan bahwa seluruh TPMPS sudah melakukan tugasnya dengan baik, narasumber dalam pelatihan pun sesuai dengan apa yang diharapkan sekolah. Sama halnya dengan pemenuhan mutu standar isi, guru-guru yang megikuti kegiatan workshop pun serius dan sudah memahami bagaimana metode pembelajaran dan pembuatan RPP yang sesuai dengan kebutuhan siswa dalam pencapaian visi, misi dan tujuan sekolah.

Pelaksanaan monitoring dan evaluasi yang keempat adalah standar penilaian. Kegiatan yang dilaksanakan dalam pemenuhan mutu standar penilaian sama seperti halnya kegiatan yang dilakukan dalam pemenuhan standar isi dan standar proses. Tetapi dalam simpulan yang dilakukan oleh panitian monev menyarankan untuk melakukan kegiatan pelatihan kembali, untuk memberikan pemahaman lebih kepada guru-guru terutama dalam penyusunan kisi-kisi soal, penyusunan butir-butir soal, analisis hasil belajar dan menindaklanjuti hasil penilaian semester sebelumnya, sehingga terlihat progress peserta didik dalam pemahaman pembelajaran sejauh mana.

\section{Hasil Perbaikan Mutu SMP Darul Falah Cihampelas}

Hasil perbaikan mutu di SMP Darul Falah akan berdampak pada kegiatan pembelajaran, prestasi siswa dan pencapaian sekolah, kepuasan pelanggan juga pemenuhan seluruh standar nasional pendidikan. Dampak yang sangat terlihat dan dirasakan setelah hasil penerapan SMPI yaitu mempermudah sekolah saat pelaksanaan akreditasi sekolah. Dengan adanya SMPI secara tidak langsung manajerial sekolah pun lebih tertata, kelengkapan dokumen dan arsip sekolah lebih termanajemen dari tahun sebelumnya. Sehingga saat sekolah melaksanakan akreditasi sekolah tidak begitu banyak mempersiapkan dokumen dan arsip sekolah yang diperlukan saat akreditasi dilakukan. SMP Darul Falah terakreditasi A dengan nilai sebelum diterapkan SPMI 93, dan nilai setelah diterapkan SPMI 95. Dengan akreditasi ini keberadaan sekolah diakui oleh pemerintah dan seluruh kegiatan dapat ditinjau oleh pemerintah.

Selain dalam proses akreditasi sekolah, peningkatan prestasi siswa secara keseluruhan dari tahun pertama diterapkannya SPMI jauh meningkat. SMP Darul Falah sudah banyak mengirimkan peserta didiknya pada perlombaan-perlombaan resmi yang diadakan oleh pemerintah seperti OSN lomba matematika, IPA, IPS dan O2SN seperti lomba renang, bulutangkis, karate, atletik, dan kegiatan-kegiatan lainnya baik itu tingkat Provinsi, Kabupaten, dan Gugus. Berikut merupakan daftar data prestasi peserta didik SMP Darul Falah Cihampelas.

Untuk tolak ukur keberhasilan penerapan SMPI dapat dilihat melalui kepuasan pelanggan, seberapa puas pelanggan terhadap keberadaan SMP Darul Falah dapat dilihat melalui kepuasan pserta didik sebagai objek dari pendidikan di SMP Darul Falah dan juga alasan mengapa orang tua peserta didik menyekolahkan anaknya di SMP Darul Falah.

\section{Penetapan Standar Mutu Baru SMP Darul Falah Cihampelas}

Tahapan atau siklus terakhir dalam penerapan SPMI di SMP Darul Falah yaitu pemetaan standar mutu baru. Yakni kesimpulan dan perencanaan kembali 
setelah pelaksanaan SPMI selama satu tahun kebelakang. Dari hasil monitoring dan evaluasi dapat dilihat dan dirasakan perubahan yang terjadi di SMP Darul Falah. Pada saat penetapan standar baru tim pengembangan sekolah menganalisis kembali hasil rapot mutu setelah diterapkannya SPMI apakah meningkat sesuai dengan target, atau menurun, atau tidak ada perubahan. Perencanaan dan pelaksanaan yang dilakukan pada tahun penerapan SPMI di SMP Darul Falah dilaksanakan dalam kurun waktu akademik Juli 2016, 2017/2018 - 2018/2019.

Kelengkapan dokumen dari setiap penyelenggaraan sistem penjaminan mutu internal menjadi tolak ukur dalam penetapan atau perencanaan kembali standar mutu yang perlu diperbaiki. Dengan demikian tim pengembangan mutu sekolah tidak perlu melakukan perencanaan ulang melainkan melakukan perencanaan lanjutan saja, atau meneruskan dan mengurangi atau menambahkan rencana yang sudah di tetapkan.

Dari hasil penerapan tersebut dapat dilihat perubahan dan penilaian dari pemenuhan seluruh stanar nasional pendidikan yang menjadi skala prioritas untuk di lakukan perubahan yaitu ada empat standar (standar kompetensi lulusan, standar isi, standar proses dan standar penilaian) dan empat standar yang blum di lakukan perubahan tetapi sejalan dengan diterapkannya SPMI ikut meningkat pula. Hal ini dapat dilihat dalam gambar berikut ini.

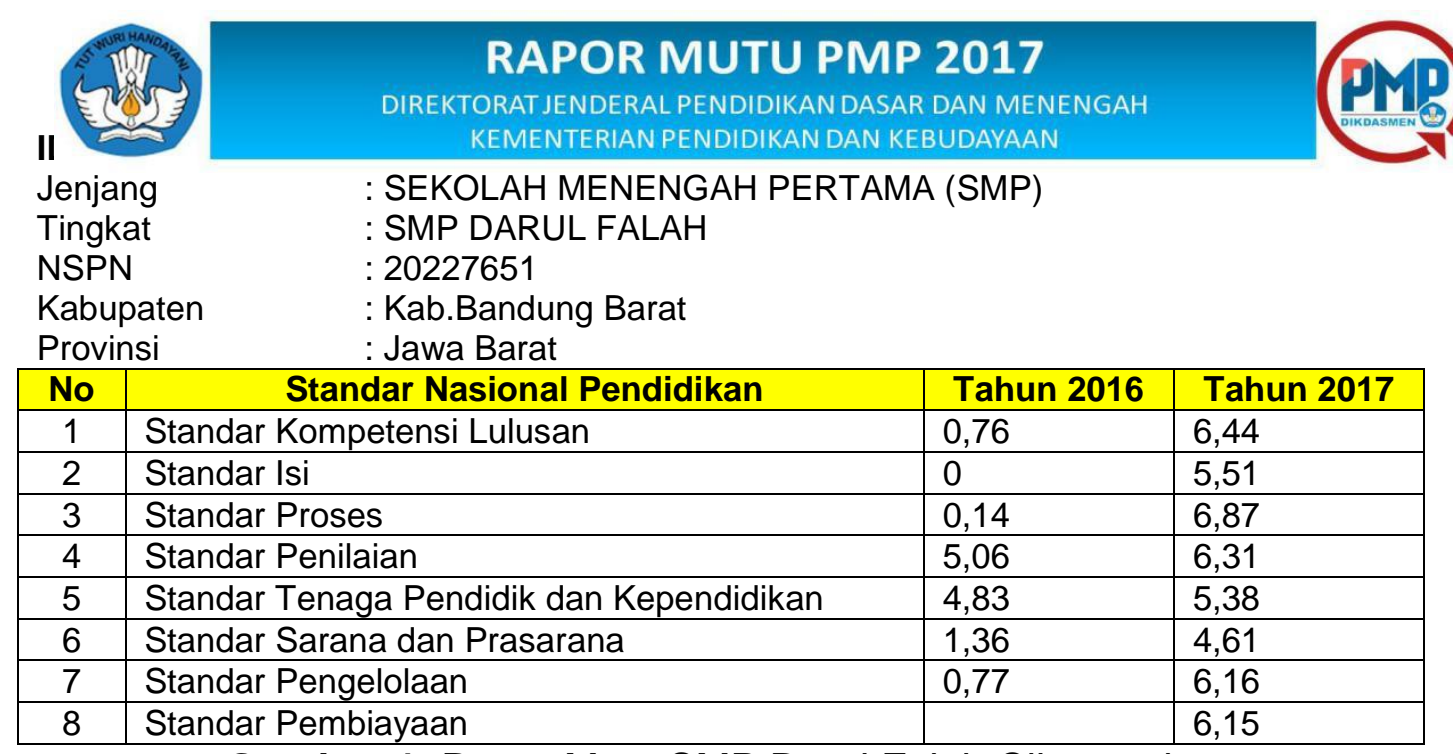

Gambar 1. Rapot Mutu SMP Darul Falah Cihampelas Kabupaten Bandung Barat

Dari rapot mutu tersebut dapat terlihat jelas pencapaian yang berhasil dilakukan dalam perbaikan mutu pendidikan di SMP Darul Falah. Meski belum mencapai batas atas yaitu dengan nilai 7 sesuai dengan pedoman dari pemerintah dalam melaksanakan pemenuhan mutu pendidikan, tetapi hasilnya sudah sangat baik.

Untuk lebih memajukan keberhasilan pendidikan terkait pemenuhan mutu standar nasional pendidikan maka SMP Darul Falah perlu melakukan perencanaan ulang, dengan lebih meluaskan perbaikan ke seluruh delapan standar nasional pendidikan. Perencanaan awal yang dilakukan ialah 
melakukan identifikasi capaian SNP pada rapot mutu tahun sebelumnya, lalu tentukan $45 \%$ indikator mutu yang menjadi target pemenuhan mutu pada tahu yang akan datang (2019/2020).

\section{SIMPULAN}

Pemetaan mutu di SMP Darul Falah dilakukan dengan menganalisis rapot mutu sekolah atau dinamakan dengan Evaluasi Diri Sekolah (EDS), untuk mengetahui sejauh mana perkembangan sekolah sebelum diterapkannya SPMI.

Perencanaan penigkatan mutu di SMP Darul Falah dirumuskan oleh seluruh Tim Pengembang Mutu Sekolah (TPMS) dengan bimbingan Lembaga Penjaminan Mutu Pendidikan (LPMP). Dalam proses perencanaan dilakukan beberapa tahap, mulai dari penetapan kembali TPMS sekolah menjadi TPMS SPMI, melakakuan analisi EDS dan analissi SWOT.

Pelaksanaan peningkatan mutu di SMP Darul Falah dilaksanakan sesuai dengan hasil EDS, yaitu memfokuskan perbaikan ke empat Standar Nasioanal Pendidikan yang termasuk kedalam standar akademik (Standar Isi, Standar Proses, Standar Penilaian, Standar Kompetensi Lulusan).

Monitoring dan Evaluasi peningkatan mutu di SMP Darul Falah dilakukan oleh Tim Monev. Dengan pengawasan dari setiap pelaksanaan peningkatan mutu internal SMP Darul Falah dan melakukan evaluasi terhadap pelaksanaan yang perlu diperbaiki.

Perencanaan mutu kembali atau perbaikan mutu kembali di SMP Darul Falah meliputi analisis persamaan antara rapot mutu tahun sebelumnya dan rapot mutu tahun sekarang. Dengan demikian dapat dilihat progres penerapan SMPI di sekolah. Dan merencanakan kembali standar apa yang belum sesuai dengan target atau perencanaan standar nasional pendidikan yang belum dilakukan perbaikan.

\section{REFERENSI}

Asia. (2017). Implementasi Sistem Penjaminan Mutu Internal Sebagai Upaya Meningkatkan Mutu Pendidikan Di SMP Negeri 3 Palu. Jurnal Administrasi Publik, 13(1). Diambil dari jurnalap.org/index.php/jap/article/view/77/60

Direktorat Jenderal Pendidikan Dasar dan Menengah. (2016). Petunjuk Teknis Pengembangan Sekolah Model dan Pola Pengimbasan. Jakarta: Kementerian Pendidikan dan Kebudayaan.

Gaspersz, V. (2005). Total Quality Management. Jakarta: PT Gramedia Pustaka Utama.

Hardianto. (2016). Penerapan Manajemen Mutu Terpadu Pada Lembaga Pendidikan Islam. HIKMAH: Jurnal Pendidikan Islam, 5(2), 165-182. http://ojs.staituankutambusai.ac.id/index.php/hikmah/article/view/29/27

Hendrowati, T. Y. (2016). Implementasi Sistem Penjaminan Mutu Sekolah pada SMPN 25 Bandar Lampung. Jurnal E-DuMath, 2(3). Diambil dari https://ejournal.stkipmpringsewu-

lpg.ac.id/index.php/edumath/article/download/189/132 
Jamaluddin, J., \& Sopiah, S. (2018). Desain Sekolah Model: Studi Penjaminan Mutu Pendidikan. IJER (Indonesian Journal of Educational Research), 2(2), 99. https://doi.org/10.30631/ijer.v2i2.47

Menteri Pendidikan dan Kebudayaan Republik Indonesia. (2016). Peraturan Menteri Pendidikan Dan Kebudayaan Republik Indonesia Nomor 28 Tahun 2016 Tentang Sistem Penjaminan Mutu Pendidikan Dasar Dan Menengah. Jakarta.

Puspitasari, H. (2018). Standar Proses Pembelajaran Sebagai Sistem Penjaminan Mutu Internal di Sekolah. Muslim Heritage, 2(2), 339. https://doi.org/10.21154/muslimheritage.v2i2.1115

Sani, R. A., Arifin, R. S., Rif'an, M., \& Triatna, C. (2018). Sistem Penjaminan Mutu Internal. Tangerang: Tiara Smart.

Sugiyono. (2014). Metode Penelitian Pendidikan (Penelitian Kuantitatif, Kualitatif dan $R \& D)$. Bandung: Alfabeta.

Suharsaputra, U. (2013). Administrasi Pendidikan. Bandung: Refika Aditama.

Uchtiawati, S., \& Zawawi, I. (2014). Penerapan Penjaminan Mutu Pendidikan pada Sekolah Menengah Atas berstandar Internasional. Jurnal Kebijakan dan Pengembangan Pendidikan, 2(1), 2-56.

http://ejournal.umm.ac.id/index.php/jmkpp/article/viewFile/1735/1829

Umam, K. (2014). Manajemen Perkantoran. Bandung: CV Pustaka Setia. 